\title{
Key Components and Critical Success Factors for Project Management Success: A Literature Review
}

\author{
Sarath Herath \\ Graduate School of Management, \\ Management and Science University, Malaysia \\ E-mail: absherath@gmail.com (Corresponding Author) \\ Siong Choy Chong \\ Finance Accreditation Agency, Malaysia \\ E-mail: eddychong@faa.org.my
}

\begin{abstract}
This paper aims to comprehensively identify the key project components and their associated critical success factors (CSFs) contributing to project management success in the context of the construction industry. Although the CSFs have been documented in the literature, insofar there has been no attempt to consolidate them. An extensive search of literature was conducted on the Internet and publication databases using multiple keywords which include, inter alia, 'project management success', 'critical success factors in construction projects' and 'key project components'. As a result, this paper proposes five key project components (project human resources management, project design package, project management efficiency, project stakeholder management and project budget) and their unique CSFs contributing to project management success specifically for construction projects, along with some common CSFs such as top management support and commitment in terms of clear direction, communication, technical and skills development, as well as providing a conducive cultural work environment and friendly environmental factors which apply to all types of projects. The resulting outcomes fetch research and managerial implications which are detailed in the body of the paper.
\end{abstract}

Keywords: project management success, critical success factors, project human resources management, project design package, project management efficiency, stakeholder management, project budget

\section{INTRODUCTION}

A project is defined as a temporary endeavour in the activities undertaken to arrive at a specific result, product and/or service. It is concluded when its objectives have been terminated, whether or not they have been met. Whilst projects always bring about new products or services that have not existed before, the methods, processes and activities involved are never the same (Barron and Barron, 2009). Project management, on the other hand, includes cyclical planning, organising, monitoring and controlling of all aspects of a project to achieve its objectives (Alam, 2009; Chan et al., 2009) in terms of cost, time, quality (De Wit, 1988; Kerzner, 1998) and environmental concerns (Mir and Pinnington, 2014), providing a broad base definition of project management success.
Despite the progress in the field, however, the definitions of project success and project management success remain ambiguous. The terminologies of project success and project management success may appear to be similar as both concentrate on achieving success, but they should be seen as distinct concepts although they are related to each other. De Wit (1988) and Nicholas (1989) make an interesting distinction between project success and project management success where projects can still be classified as successful despite poor project management. A classic example is the Sydney Opera House Project (Thomsett, 2002) where the project was a major success for the people but it was a failure from the project management point of view.

Project success often concentrates on task completion, whereas project management success is defined as planning, directing and controlling of resources to meet the technical, cost and time constraints of a project (Jacobs and Chase, 2018), including environmental concerns (Mir and Pinnington, 2014). Although project management is wider in scope, Baker et al. (1988) and Pinto and Slevin (1988) elucidate that there is no simple answer and conclude that there are multiple factors which affect project management success. In essence, the definition of project management success should not be limited to broad base assumptions on the predefined constraints of cost, time, quality and environmental concerns. Instead, the focus should be on why and what contributes to the success (or failure) to comply with the said constraints. This points to the need to identify the key project components along with their critical success factors (CSFs) that ought to be planned, managed, monitored and controlled to accomplish projects within the agreed cost, stay within project schedule, work completed with acceptable quality, taking into consideration environmental concerns such as political, legal, institutional, cultural, sociological, technological, economical, financial and physical infrastructure (Hughes, 1989; Walker, 1989; Zhang, 2011).

Having said so, most of the studies to date have concentrated on the CSFs either on one or several key project components (see Table 1 and section 2.3 for details), giving a cursory view of what project management success means. This study aims to carry out a comprehensive review of the literature on the key or fundamental components affecting project management success, along with their associated 
CSFs. The theoretical and managerial implications arising from this review are discussed before the paper is concluded with future research directions.

\section{LITERATURE REVIEW}

\subsection{Review Approach}

The process of review and analysis of literature was carried out based on the cue by Gunasekera and Chong (2018). It began with the search on the Internet and publication databases, using multiple keywords, which include, inter alia, 'project management success', 'critical success factors in construction projects' and 'key project components'. In addition, relevant publications such as Project Management Body of Knowledge (PMBOK) Guide (2017), theses and books were referred to. This has resulted in the identification of a considerable number of CSFs, which enabled the key project components to be determined. The results of the review and its analysis are presented in the following sub-sections.

\subsection{Critical Success Factors}

Rockart (1979), who was the first to introduce CSFs in the context of project management (called factors producing success of projects), defines CSFs as the critical areas of project activities that should receive continuous and careful attention from managers since these factors will have a significant impact on project management success if they are properly managed, maintained and controlled (Leidecker and Bruno, 1984; Pinto and Slevin, 1987).

In evaluating the CSFs, three distinct situations need to be addressed (Dvir et al., 1998). The situations comprise factors leading to project management success, factors leading to successful projects and factors leading to consistently successful projects (Cooke-Davies, 2002). Cooke-Davies (2002) further points out two distinctions: (1) by distinguishing between project success (measured against the overall project objectives) and project management success (measured against existing traditional measurement performance of cost, time and quality); and (2) by distinguishing between the success criteria (measures of success and failure of a business or a project) and success factors (those input to the management system that leads directly to the success of the project). These provide the grounds for the current research to be conducted.

In addition, CSFs have also been categorised according to common and unique CSFs. The common CSFs are considered as factors necessary for success in any project undertaken regardless of the sector the project belongs to. On the other hand, the unique CSFs are considered as the key or essential project components in achieving project management success. Table 1 shows the list of common and unique factors contributing to project management success proposed by studies ranging from 1995 to 2020 .

Table 1 Critical success factors influencing project management success

\begin{tabular}{|c|c|c|}
\hline Researchers & Common CSFs & Unique CSFs \\
\hline $\begin{array}{l}\text { Chan and Kumarasamy (1997) } \\
\text { Chan and Yeong (1995) } \\
\text { Flyvbjerg (2004) } \\
\text { Mohamed (2001) Stasinopoulos et al. } \\
\text { (2009) }\end{array}$ & $\begin{array}{l}\text { Top management support, schedule and plan, } \\
\text { communication }\end{array}$ & Design package \\
\hline Ashley et al. (1987) & Leadership qualities & $\begin{array}{l}\text { Project manager capabilities and experience, } \\
\text { scope and work definition }\end{array}$ \\
\hline Pinto and Slevin (1987) & $\begin{array}{l}\text { Top management support, schedule and plan, } \\
\text { communication }\end{array}$ & Human resources, stakeholder management \\
\hline Pinto and Prescott (1988) & $\begin{array}{l}\text { Top management support, adequate technical } \\
\text { support }\end{array}$ & $\begin{array}{l}\text { Clear scope identification, consultation with } \\
\text { stakeholders, adequate resource allocation }\end{array}$ \\
\hline Verma $(1995,1996)$ & Leadership qualities & $\begin{array}{l}\text { Effective human resource management, efficient } \\
\text { project manager }\end{array}$ \\
\hline Belassi and Tukel (1996) & Commitment to project success & Project manager, project team members \\
\hline Nicolini (2002) & & Budget control \\
\hline Dong et al. (2004) & $\begin{array}{l}\text { Top management support, communication, the } \\
\text { ability of clients to make quick decisions, technology } \\
\text { support }\end{array}$ & $\begin{array}{l}\text { Project manager and team members, stakeholder } \\
\text { involvement }\end{array}$ \\
\hline Nguyen et al. (2004) & Commitment to project success & $\begin{array}{l}\text { Competent project manager, competent project } \\
\text { team }\end{array}$ \\
\hline Spalek (2005) & Communication & $\begin{array}{l}\text { Project scope (design } \\
\text { resources, project budget }\end{array}$ \\
\hline $\begin{array}{l}\text { Cooke-Davies (2014) } \\
\text { Dvir et al. (2006) }\end{array}$ & Top management recognition & $\begin{array}{l}\text { Efficient project management, efficient project } \\
\text { management }\end{array}$ \\
\hline Ugwu et al. (2006) & Top management support, use of proper technology & $\begin{array}{l}\text { Clear project definition, the skill level of project } \\
\text { team }\end{array}$ \\
\hline Jha and lyer (2007) & Commitment, communication & $\begin{array}{llll}\begin{array}{l}\text { Competent project } \\
\text { stakeholders }\end{array} & \text { manager, competent } \\
\end{array}$ \\
\hline Toor and Ogunlana (2008) & $\begin{array}{l}\text { Top management support, learning from past } \\
\text { projects, technology support }\end{array}$ & $\begin{array}{l}\text { Stakeholder consultation, effective project } \\
\text { management, competent team members, budget } \\
\text { control, design document. }\end{array}$ \\
\hline De Silva et al. (2008) & Quality & $\begin{array}{l}\text { Financial, skilled resources, efficient project } \\
\text { management }\end{array}$ \\
\hline
\end{tabular}


Table 1 Critical success factors influencing project management success (con't)

\begin{tabular}{|l|l|l|}
\hline \multicolumn{1}{|c|}{ Researchers } & \multicolumn{1}{|c|}{ Common CSFs } & \multicolumn{1}{c|}{ Unique CSFs } \\
\hline Saqib et al. (2008) & $\begin{array}{l}\text { Top management support, communication, } \\
\text { technology support }\end{array}$ & Project management, project definition \\
\hline Park (2009) & Commitment, communication & Good budget estimate \\
\hline Chan et al. (2009) & Top management support & Clear project definition, good resource availability \\
\hline Limodio (2011) & Cultural and environmental & Good budget, good design package \\
\hline $\begin{array}{l}\text { Kaming et al. (1997) } \\
\text { Ogwueleka (2013) }\end{array}$ & $\begin{array}{l}\text { Top management support, financial support, } \\
\text { commitment of participants }\end{array}$ & $\begin{array}{l}\text { Good budget, availability of skilled manpower, } \\
\text { management of design document, stakeholder } \\
\text { management }\end{array}$ \\
\hline Davis (2014) & Top management support, communication, benefits & Stakeholder satisfaction, clear definition of project \\
\hline Silva et al. (2015) & $\begin{array}{l}\text { Top management support, clear scope, training, skill } \\
\text { development }\end{array}$ & $\begin{array}{l}\text { Good budget, stakeholder management, human } \\
\text { resources }\end{array}$ \\
\hline Taherdoost and Keshavarzsaleh (2015) & Environmental factors & Project manager skills, team member skills \\
\hline Aneesha and Haridharan (2017) & $\begin{array}{l}\text { Top management support, good communication, } \\
\text { commitment of the group, good leadership }\end{array}$ & $\begin{array}{l}\text { Competent project manager, competent project } \\
\text { team, good financial package }\end{array}$ \\
\hline Buvik and Tvedt (2017) & $\begin{array}{l}\text { Clear roles and responsibilities, comprehensive } \\
\text { control, clear directions }\end{array}$ & $\begin{array}{l}\text { Experienced project manager, experienced } \\
\text { project team }\end{array}$ \\
\hline Alleyne et al. (2018) & Environmental factors & Budget control \\
\hline Frefer et al. (2018) & Stakeholder satisfaction \\
\hline Li et al. (2019) & Top management support & $\begin{array}{l}\text { Efficient project management, clear project } \\
\text { definition, stakeholder management }\end{array}$ \\
\hline Viles et al. (2019) & Top management support & \begin{tabular}{l} 
Good budget \\
\hline Gumay et al. (2020)
\end{tabular} \\
\hline Yudhistyra et al. (2020) & management \\
\hline
\end{tabular}

\subsection{Analysis and Observations}

The studies shown in Table 1 indicate that some of the CSFs have received research attention since 1995. Amongst the common CSFs identified include top management support and commitment in terms of clear direction, communication, technical and skills development, as well as providing a conducive cultural work environment and friendly environmental factors. These CSFs are labelled as common as they apply to all types of projects, including those beyond the construction setting.

In an attempt to cluster the unique CSFs, which is the backbone of this study, they fall into five categories of key project components based on the keywords used and their contexts within the literature. Amongst the key components, project human resources management seemed to have received the greatest research attention, followed by project design package, project management efficiency, project stakeholder management and project budget. Table 1 also implies the fragmentation of studies conducted on the CSFs or the key project components. There have been studies combining several key project components although insofar none of the individual studies have covered all the five key project components in a single study.

The key project components and their associated CSFs, as well as their link to project management success, are elaborated in the following section.

\section{CONCEPTUAL REVIEW OF THE KEY PROJECT COMPONENTS AND THEIR CRITICAL SUCCESS FACTORS}

\subsection{Project Human Resources Management}

Pryke and Smyth (2006) found that allocation of human resources to projects, monitoring performance and motivation are important dimensions of project management success. In fact, some researchers have acknowledged the management of human resources as one of the critical factors leading to project management success (Belout, 1998; FitzEnz, 1984; Ulrich, 1987). Specifically, Bayilev and Teklu (2016) point out that the competence of key manpower, with their ability and experience to understand the dynamics of project environment, is a key success factor for projects funded by the European Union. This could be the reason why this key project component has received the greatest research attention so far.

Successful implementation of a strategic plan leading to project management success is influenced by the behaviours of organisations and organisational direction (Belout, 1998; Rogers, 1990; Thornberry, 1987). Indeed, the commitment from top management to implement projects and systems is well-documented (Somers and Nelson, 2001). Such support and commitment include identification and recruitment of skilled personnel, motivation and proper communication, including organisational goals, with employees. The efforts include developing an apt organisational structure and building a conducive culture (Kumar et al., 2021). Bangi et al. (1999) insist that there is no other factor as effective as the recognition and support from the top management in predicting performance management success.

Top leaders of construction organisations also play an important role to ensure that organisational members have the requisite skills (Yudhistyra et al., 2020). An effective human resource function will help to identify and compile such organisational abilities, as well as audit and keep track of skills development (Mayfield et al., 2016). Indeed, selecting the best human resources for a project requires a good understanding of the project requirements, along with identifying the various skills that are necessary to manage the project. Failure to recognise the levels of skills required for a project by managers will contribute to poor quality work, backlogs and rework (Lee et al., 2010). 
However, estimating the actual human resources required for a project in practice is often complicated, which requires efforts and time (Newton, 2008). In addition, conflicts and disputes over loyalty and power are common in the allocation of human resources (Jacobsen and Thorsvik, 2007; Kerzner, 2009; Payne, 1995). Hence, the allocation of human resources, particularly in large multi-project organisations, should be done taking into consideration these challenges, as well as the temporary working conditions and changes in human resource allocation (Engwall and Jerbrant, 2003; Huemann et al., 2007), focusing on meeting the needs of employees (Bondarouk et al., 2019).

Hence, managing project human resources require special skills too, with the critical ones include selecting, training and managing resources, with special attention paid to motivating, communicating, organising and managing project teams (Demilliere, 2014; Schuler, 1992). Project managers play a key role in the selection and motivation of key human resources, providing necessary training and demanding total commitment from everyone in the project team to achieve project management success. For this, Somers and Nelson (2001) identify the following CSFs for project human resources management: (1) top management support; (2) recognition by top management; (3) availability of technology; (4) availability of right skills; (5) training to perform specific tasks; (6) availability of proper training facilities; and (7) clear identification of goals. The skills required to go beyond the tasks of the projects include the ability to understand how the environmental factors impact on projects and vice-versa, as well as the ability to maintain quality through continuous monitoring.

\subsection{Project Design Package}

Besides project human resources management, a considerable number of studies have emphasised that a wellformulated basic and detailed design package is the key requirement for project management success (Chan and Kumarasamy, 1997; Chan and Yeong, 1995; Flyvbjerg, 2004; Mohamed, 2001; Toor and Ogunlana, 2008). Although bad project implementation can harm structurally solid projects, good implementation cannot make structurally weak projects successful (Limiodo, 2011), suggesting the importance of a proper initial design package. A recent survey carried out by PWC (2018) confirmed a wellprepared design package to be the most prevalent key project component for project management success.

The importance of a good project design package is amplified by the fact that it determines $80 \%$ of the cost of the entire project (Stasinopoulos et al., 2009). Hamilton (2007) provides a typical example of the Scottish House of Parliament where poor initial design has led to more than 545 design changes in a month, with a 20 -month delay to the original schedule and cost overruns of $£ 230$ million. Other examples of bad designs reported which fetched negative consequences on project cost and delays included the Kuala Lumpur International Airport (Ghazali, 2015; Yap et al., 2015) and the Victoria-based Australian pipeline project (Han et al., 2013; Orangi et al., 2011). In fact, poor initial design or subsequent design changes has been recognised as the most common reason for project delays and budget overruns, leading to either rework or new designs (Alnuaimi et al., 2010; Chan and Kumarasamy, 1997; Chan and Yeong,
1995; Flyvbjerg et al., 2003, 2004; KPMG, 2012; Lovins et al., 1999; Morris, 2000; Viles et al., 2019; Toor and Ogunalana, 2008).

The ITC Project Design Manual (2010) specifically highlights the need to spend more time on developing the project design and data collection, even though very often little time is devoted to the design phase due to the scarcity of human resources. In addition, designing a project requires an upfront investment, in which the top management of many organisations is less willing to do so.

Project design is a structured activity (Table 2), including many downstream activities such as construction drawings, specifications, procurement packages, datasheets, project technical documents, as well as methodologies for system development which depend heavily on a good project design package. Hamilton (2007) emphasises that the primary design should not be rushed before the outcomes of the conceptual design is known, taking into consideration expectations of clients and other external stakeholders, as well as the possible changes in the environment which include technology, geological, innovation, market opportunities and pressure from the owners, community groups, amongst others. Stasinopoulos et al. (2009) also stresses on the need for $21^{\text {st }}$ century designs to consider the effect of the projects on safety and the environment. Hamilton (2007) further adds that design control during the later stage of the project and the post-design phase is required to be managed carefully to avoid any massive cost, quality or even time impact on the project.

Table 2 Activities involved in project design

\begin{tabular}{|l|l|}
\hline \multicolumn{1}{|c|}{ Stage } & \multicolumn{1}{c|}{ Description } \\
\hline Pre-design & $\begin{array}{l}\text { This is the initial phase which addresses the } \\
\text { key requirements of the project and is } \\
\text { typically merged with the conceptual design } \\
\text { stage. }\end{array}$ \\
\hline Conceptual design & $\begin{array}{l}\text { This phase studies the design solutions, } \\
\text { definitions of shapes and spaces, materials } \\
\text { and building systems. Proper evaluation of } \\
\text { this stage is sacrosanct to achieve a good } \\
\text { initial design. }\end{array}$ \\
\hline General design & $\begin{array}{l}\text { Plans, major systems and materials are } \\
\text { taken to a higher level of detail, along with } \\
\text { the estimation of the overall cost of the } \\
\text { project. }\end{array}$ \\
\hline $\begin{array}{l}\text { Construction } \\
\text { design }\end{array}$ & $\begin{array}{l}\text { This phase generates the final set of } \\
\text { documents for use in construction activities. } \\
\text { It includes detailed drawings, specifications } \\
\text { of systems and materials, site work plans } \\
\text { and acceptance criteria. }\end{array}$ \\
\hline
\end{tabular}

Ogwueleka (2013) elucidates that the use of efficient project management methods and systems, as well as to ensure inclusion of proper technical content and skilled personnel are significant CSFs in the preparation of the project design document, without which this will lead to negative consequences on cost and schedule due to changes in design (Olawale and Sun, 2010). Since the development of the project design package is a collaborative effort, it is imperative for project designers with expertise in different technical fields to work with each other to maintain quality (Mohandas and Sankaranarayanan, 2008). This requires a shared vision of functions and organisational structure that are achieved through communication, which is vital to 
incorporate the different yet contradicting requirements of clients and stakeholders. The design team must agree on the basis of the design, i.e. basic codes and standards, design parameters, types of documentation required, risk analysis, to name a few. For this, the skill level of project team members is imperative (Chan and Kumarasamy, 1997), especially in recognising the separation between project design and the actual construction activities.

In short, the CSFs for project design package includes an efficient communication system with a high level of coordination, sufficient time allocation for comprehensive preparation of the project design package, skilled personnel working in a collaborative environment, paying attention to the environment, as well as taking into consideration the requirements of different stakeholders (Koskela, 1992). In fact, Deming (1986) stresses that the importance of quality design must be understood by all concerned from the inception of any project. Further care needs to be taken to ensure that the prepared design package contains the initial specifications without compromising the design.

\subsection{Project Management Efficiency}

Project management efficiency has since become an important issue for many developing countries due to its effectiveness in attaining the desired project goals and objectives (Haron et al., 2017). In fact, the importance of efficient project management is pronounced in many studies (Ballard and Koskela, 1998; Haider et al., 2011; Mohandas and Sankaranarayanan, 2008). Accordingly, efficient project management entails functions that must be controlled and coordinated by the project management group. Specifically, the managerial skills of project managers, their technical background, project attributes and environmental factors are critical for efficient project management. However, the conflict between the so-called ideal project management best practices followed by many project managers and the reality of each project having unique requirements has many inherent conflicts (Newton, 2008). Although standardised project management practices bring advantages, they do not work in all situations and may even increase the risks of a project failure.

Many studies have acknowledged that the project manager is the central figure in determining project success and project management success (Cleland, 1984; Kezsbom et al., 1989; Nicholas, 1994). One primary function of the project manager is to manage and gratify a variety of stakeholders by considering their expectations and needs (Mali and Waghmare, 2016). Hence, the project manager is not only involved in technical realities but should also understand the surrounding community and the people in it. Although it is challenging to map the power and interests of stakeholders (Bourn and Weaver, 2010; Collinge, 2016), if the project manager fails to judge the thoughts of stakeholders, project failure will result.

The project manager also plays a vital role in managing the preparation of design documents (Ogwueleka, 2013). Proper design coordination, communication with stakeholders and skills availability are some of the key essentials required for a successful design package, in which the project manager has a key responsibility. If the project manager fails in any of these activities, the result will be a sub-standard design package (Ghazali, 2015; Ng, 2015) which leads to cost overruns and schedule delays (Orangi et al., 2011). Similarly, the project manager is also responsible for the preparation of project budget (Haider et al., 2011; Hamilton, 2007; Mohandas and Sankaranarayanan, 2008), management and control of unplanned work that creeps into the project which severely drains the resources, agreed budget and undermine the schedule.

It is for these reasons that project managers must be recognised as a leader and have sound understanding of rules, expectations and assumptions for all the stakeholders to follow (Ahmed, 2008). In addition, project managers must also demonstrate strong leadership quality to motivate and guide project staff, excellent communication skills, foster teamwork and the ability to control projects and resolve conflicts (Cleland, 2004; Kerzner, 2006; Larkin and Larkin, 1996; Laufer et al., 1990; Verma, 1995, 1996). Project managers must also allocate more time for planning, identifying problems, as well as training and developing their line managers and project teams, recognising that project management is not an isolated role (Johnson, 1999). These imply that although project managers must have some technical background, they need not have all the technical expertise to direct the project single-handedly (Verma, 1995) but to recognise, coordinate, delegate and direct project staff to find answers (Mandson and Selnes, 2015; Sahlin, 1998).

In short, efficient project managers must manage, control and mediate on all of the key project activities. These include efficient communication, coordination, planning and motivating all project stakeholders (Cleland, 1984; Kezsbom et al., 1989; Nicholas, 1994). He or she should possess sufficient experience to achieve the main objectives of projects in overcoming the constraints of cost, time and quality (Chen, 1997; Cleland, 1999; Cleland and Gareis, 1994; Harrison, 1992; Keeling, 2000; Kerzner, 1998). In addition, he or she should demonstrate environmental concerns through the ability to recognise and implement the Environmental Impact Assessment on projects (Shah et al., 2010). He or she must develop a true sense of belonging to the organisation and develop training and an effective measurement system for each project using appropriate practices and strategies.

\subsection{Project Stakeholder Management}

A stakeholder is a person or an organisation who or which is committed and stands to gain or lose from the success of a project, irrespective of whether they affect and/or are affected by the project deliverables (El-Gohary et al., 2006). In a typical project, stakeholders may consist of the sponsors, stockholders, general public, project directors, project managers and other relevant project personnel (Leung et al., 2004). In other words, they could be internal or external to the project organisation who may be superficially or totally involved in a project.

Because of their diverse occupational, professional backgrounds and interests, the interests, goals and expectations between the internal and external stakeholders, as well as within them often differ, creating conflicts with each other (Buotelle, 2004). It is common for different stakeholders to attempt to exert their influence to push their objectives into projects by means of advancing, interfering or blocking projects (Swift, 2019). 
Hence, stakeholder management is an important component which influences project management success (Abdullah et al., 2010; Jepsen and Eskerod, 2009; Jergeas et al., 2000; Liang et al., 2017; Ogwueleka, 2013; PWC, 2018). Project organisations that consistently maintain good relationships, characterised by a mutual trust with their stakeholders often have a competitive advantage over those which do not (Barney and Hansen, 1994). In fact, poor stakeholder involvement has been identified as one major reason for project failures in developing countries since their behaviour impact schedules, attention to cost control and environmental due to poor decision making (Davis, 2014; Eyiah-Botwe, 2015). Hence, it is paramount for management to sustain stakeholder management (Multaharju, 2016) by making sure that all stakeholders collaborate in the project for project management success (Bond-Barnard et al., 2018).

In addition, the political and cultural environments also play a significant role in shaping the interests, influence and behaviour of stakeholders in deciding cost, schedule and impact on the environment, particularly in developing countries where mega projects with integrated procurement is involved (Aapaoja and Haapasalo, 2014; Gudienè et al., 2013; Mok et al., 2015). A project without political support will experience major and critical barriers to get cost, schedules and even environmental approvals (Eyiah-Botwe et al., 2015). Similarly, community groups fighting for environmental protection also exert significant influence on projects. For instance, large dam projects, which have a profound irreversible environmental impact and reduce the availability of land, are likely to face opposition from the groups. Likewise, other more general projects which may contribute to water pollution, the release of carbon dioxide and which harm aquatic lives may be protested too. Reducing the environmental effect from construction projects will require collaborative efforts with the affected stakeholders.

Mali and Waghmare (2016) identify several CSFs of stakeholder management which include: (1) attitude of stakeholders; (2) interests of stakeholders; (3) confidence of project managers; (4) power of stakeholders; (5) knowledge of stakeholders; (6) effective communication; (7) satisfaction of stakeholders; (8) top management support; (9) needs of stakeholders; and (10) involvement of stakeholders. They also suggest that a competent project manager will be able to play a pivotal role to coordinate between all the stakeholders and mitigate all unnecessary interferences. In addition, the project manager must create an environment to show that the stakeholders are a very important part of the project so as to command the necessary involvement and commitment from stakeholders in making management, quality and financial decisions. An assessment to determine the degree of importance and influence of each of the stakeholder groups is imperative. Another critical aspect is communication with the stakeholders to maintain good relationships and trust with them (Barney, 1986, 1991; Cohen and Prusak, 2001), including convincing them that the recommendations made are beneficial to all. Hence, stakeholder management should be seen as a process involving systematic identification of all stakeholders, their interests, analysing engagement and offering the necessary support for successful project delivery (Eskerod and Jepsen, 2013).

\subsection{Project Budget}

Project budget refers to the amount of funds allocated to a project by clients, sponsors and the senior management group (Campbell, 2009) that represent the estimated planning of expenditure on the resources required to plan, execute and monitor a project (Newton, 2008). Many studies have concluded that budget allocation and control are essential for project management success (Chan and Kumarasamy, 1997; Chan and Yeong, 1995; Kaming et al., 1997; Mohamed, 2001; Sansone et al., 2020; Toor and Ogunlana, 2008; Viles et al., 2019). Indeed, project activities are tightly interwoven around the project budget. A survey carried out by PWC (2018) has identified project budget as one of the most prevalent factors for project management success.

Vasista (2017) found that when quantitative base information and historical base information are combined, they tend to produce better quality estimates. Besides the time length of the implementation phase of a project (Flyvbjerg, 2004), the project budget is also determined by external factors which delay the project schedule and hence cost overruns. Size of projects is another determination of cost overruns although contradictory findings have been reported. Bertisen and Davis (2008) found no relationship between project size and cost overruns although this is proven otherwise in other studies (Creedy, 2006; Odeck, 2004). Sometimes situations beyond the control of construction organisations such as weather, health, safety, political, social and economic acts may also delay the project schedule.

Since lack of control of project budget and planning impact on project management success, management must have sufficient training and education not to accept projects based on perceived value, but to revive the risk and the value it brings to the organisation (Alleyne et al., 2018). Project managers must take project length, size and foreseeable external factors, including the needs of different stakeholders into consideration as they estimate the cost of projects, with contingencies included to cover unforeseen expenditure and constant budget revisits as and when necessary, to keep the stakeholders and management happy (Alexandra, 2017).

According to Vasista (2017), amongst the CSFs for project budget preparation include: (1) project information (good specifications); (2) estimation methodology; (3) historical information; and (4) cost estimator which is supported by the maintenance of adequate quality and respect for the environment. Similarly, the Washington State Department of Transportation (2015) points out that, amongst other factors, the following considerations should be given when preparing a good cost estimate: (1) historical information; (2) good design; (3) sufficient allocation of contingencies; (4) skilled estimators; and (5) use of established estimation methods.

Having said so, cost estimation by itself is a difficult activity. Many studies have found that the actual costs have been much higher than the estimated costs (Flyvbjerg et al., 2003; Handler, 1996) for public, private and international projects as well. Cost estimation errors could be attributed to technical, physiological and political factors. The technical errors include poor design, unskilled human resources and insufficient data when allocating costs to mitigate risk, location and project type, which should be corrected over 
time. Physiological errors include over-optimism on the side of the forecasters, in which learning plays an important role. Political errors are mainly attributed to political influence, particularly on many government projects. The list of projects with cost underestimation and overruns have led to many tragedies, amongst the notable ones include the Colombia shuttle disaster in 2003 which took the lives of seven astronauts (Flyvbjerg, 2004) and the 2014 Athens Olympics which affected the credit rating of Greece.

In short, proper estimation and continuous review of project budget, management, control and maintenance against the initial project design and planning are imperative. The main objective is to provide a sufficient budget including contingencies to cover unknown factors that could result from incomplete design, as well as unforeseen conditions within the project scope. In addition, availability of valid and useful data from different stakeholders and understanding of possible cost overruns based on project length, size, as well as technical, environmental, physiological and political reasons are required. Besides the project managers taking the lead role, having skilled staff to estimate and manage schedule and resource allocation is another important factor for consideration.

\section{CONCLUSION, DISCUSSION AND IMPLICATIONS}

This paper has achieved its objectives of identifying the key project components and their associated CSFs for project management success through an extensive review of the literature. This review is based on the motivation that an attempt to consolidate the key project components and their associated CSFs contributing to project management success is yet to be made given the empirical studies available.

In this review, an attempt was made to distinguish between project success and project management success. Although the aims of both are to achieve success, project success tends to have a narrower scope, whereas project management includes the 'management' perspective, which includes the cyclical planning, organising, monitoring and controlling all aspects of a project (Alam, 2009; Chan et al., 2009; Jacobs and Chase, 2018) to meet the performance criteria of cost, time, quality and to some extent the environmental concerns. What constitutes aspects of a project give rise to the need to identify the key project components and their CSFs (Cooke-Davies, 2002) contributing to project management success.

The review approach of using multiple keywords and relying on relevant publications resulted in the identification of a comprehensive set of common and unique CSFs (see Table 1). Amongst the common CSFs, top management support and commitment have been identified as a very important factor, leading to many forms of support provided by organisations such as technical, financial, social, cultural and skilled human resources (Bangi et al., 1999; Mayfield et al., 2016; Somers and Nelson, 2001). It is therefore not surprising for these factors to be identified as common CSFs to support the unique CSFs.

The unique CSFs, on the other hand, are CSFs which are peculiar to the construction setting. The review of literature has resulted in the identification of a considerable number of CSFs contributing to project management success (Table 1), which were clustered into five key project components. They are project human resources management, project design package, project management efficiency, project stakeholder management and project budget.

The identification of the five clusters was further verified by their relationships with project management success. Specifically, the literature has confirmed the associations between project management success and project human resources management (Belout, 1998; Chan et al., 2009; De Silva et al., 2008; Fitz-Enz, 1984; Kaming et al., 1997; Ogwueleka, 2013; Pinto and Prescott, 1988; Pinto and Slevin, 1987; Pryke and Smith, 2006; Silva et al., 2015; Somers and Nelson, 2001; Spalek, 2005; Toor and Ogunlana, 2008; Ugwu et al., 2016; Ulrich, 1987; Yudhistyra et al., 2020), project design package (Chan and Kumarasamy, 1997; Chan and Yeong, 1995; Flyvbjerg et al., 2003, 2004; KPMG, 2012; Limodio, 2011; Mohamed, 2001; Ogwueleka, 2013; PWC, 2018; Spalek, 2005; Stasinopoulos et al., 2009; Toor and Ogunlana, 2008), project management efficiency (Aneesha and Haridharan, 2017; Ashley et al., 1987; Belassi and Tukel, 1996; Cleland, 1984; CookeDavies, 2014; De Silva et al., 2008; Dong et al., 2004; Dvir et al., 2006; Gumay et al., 2020; Haron et al., 2017; Jha and Iyer, 2007; Kezsbom et al., 1989; Li et al., 2019; Nguyen et al., 2004; Nicholas, 1994; Taderhoost and Keshavarzsaleh, 2015; Verma, 1995, 1996), project stakeholder management (Abdullah et al., 2010; Buvik and Tvedt, 2017; Davis, 2014; Dong et al., 2004; Eyiah-Botwe, 2015; Frefer et al., 2018; Gumay et al., 2020; Jepsen and Eskerod, 2009; Jergeas et al., 2000; Jha and Iyer, 2007; Kaming et al., 1997; Li et al., 2019; Liang et al., 2017; Mali and Waghmare, 2016; Ogwueleka, 2013; Pinto and Prescott, 1988; Pinto and Slevin, 1987; PWC, 2018; Silva et al., 2015; Toor and Ogunlana, 2008;), as well as project budget (Alleyne et al., 2018; Chan and Kumarasamy, 1997; Chan and Yeong, 1995; De Silva et al., 2008; Kaming et al., 1997; Limodio, 2011; Mohamed, 2001; Nicolini, 2002; Ogwueleka, 2013; Park, 2009; PWC, 2018; Silva et al., 2015; Spalek, 2005; Toor and Ogunlana, 2008; Vasista, 2017; Viles et al., 2019). Indeed, the discussion on each of the key project components has further yielded a more comprehensive set of CSFs for each of them and provided indication that the key project components are interrelated.

Several implications can be derived from the paper. First, the paper benefits researchers in terms of the development of an overarching framework to examine the relationships between the key project components and their associated CSFs with project management success. The combination of common and unique CSFs in every key project component as evident from the review will hopefully overcome the issue of fragmentation in future studies. More importantly, the interaction of the key project components and their associated CSFs based on the empirical data obtained could contribute to knowledge and enable a more meaningful and directed managerial implications to be derived at.

Second, since the research focused on the identification of the more popular key project components as evident from the attention given to them by researchers, the resulting review will enable researchers to expand the performance measures to cover, say cultural concerns on top of the traditional measures of cost, quality, time and environment. 
By using advanced statistical tools, cause and effect and the more important components and/or CSFs can be identified, enabling researchers to make informed recommendations to construction organisations, managers and even policy makers.

Third, the resulting review also suggests the context of which future studies can be conducted between or within developed or developing countries. Fourth, the potential moderating effects of type, size, complexity and length of projects, knowledge and skills of project managers and teams, as well as organisational factors could be considered. Fifth, as different stakeholders may exhibit different requirements, future research should consider the moderating effects of key stakeholders such as the consultants, contractors and clients. Incorporating these considerations will contribute to existing knowledge.

From the managerial perspective, it is hoped that the review provides a guide to construction organisations to better manage projects from the lens of project management success. To begin with, the literature suggests that the five key project components do not operate in isolation but complement each other, along with the common CSFs. This paper has provided a comprehensive list of unique CSFs for each key project component that the construction organisations can refer to. Appropriate plans could be formulated and supported by appropriate management support and commitment in terms of financial, technical and resources, conducive organisational structure and culture, the leadership of project managers, appropriate human resources management practices, capacity building and continuous professional development, use of effective communication channels and knowledge management system to capture and share experiences, expertise and best practices across projects, taking cognisance of the different methods, processes and activities of different projects and environmental concerns, as well as technical support where investment in relevant software may help the construction organisations to better manage and control projects and resources.

The information on the CSFs must be made available to all levels of management and within project teams, including the use of standard operating procedures (SOPs). Although the resulting key project components and their associated CSFs could be used as a checklist for the construction organisations, ideally the key project components could also serve as key result areas where key performance indicators (KPIs) against the well-defined project objectives and measures can be developed around the CSFs. Continuous monitoring and review are important to ensure that the SOPs are complied with and that the intended KPIs are achieved (Dadashzadeh, 1989) for project management success.

Although the environmental factors are beyond the control of the construction organisations, proper management of projects through the implementation of the key project components and their CSFs could help them to mitigate some threats to project management success. Besides the environmental factors highlighted in the literature, the recent COVID-19 pandemic has called for the construction organisations to manage risks through the development of a risk register that contains the probability and severity of each risk, as well as the action plans through the key project components to address them. Similarly, an understanding of the United Nation's Sustainable Development Goals may help the construction organisations to embed the key project components and the CSFs around them for better environmental and stakeholder management.

\section{REFERENCES}

Aapaoja, A., and Haapasalo, H. (2014). A framework for stakeholder identification and classification in construction projects. Open Journal of Business and Management 2(1), pp. 43-55.

Abdullah, H., Rose, R.C., and Ismad, A.I. (2010). The relationship between organisational resources, capability, system and competitive advantage. Asian Academy of Management Journal 17(1), pp. 151-173.

Ahmed, S.F. (2008). Necessity of leadership skills for project managers. SSRN, available from: https://papers.ssrn.com/sol3/papers.cfm?abstract_id=1 150083 [accessed May 23, 2019].

Alam, M. (2009). Investigating the Effectiveness of Continuing Professional Development in Project Management: A Case Study of a British Project Management Professional Development Programme. Unpublished doctoral dissertation, School of Aerospace Civil Engineering, The University of Manchester, Manchester.

Alexandra, M. (2017). Project management: 5 tips for managing your project budget. $\mathrm{CIO}$, August, available from: https://www.cio.com/article/2406862/projectmanagement-project-management-4-ways-to-manageyour-budget.html [accessed April 18, 2020].

Alleyne, P., Armstrong, S., and Chandler, M. (2018). A survey of capital budget practice used by firms in Barbados. Journal of Financial Reporting and Accounting 16(4), pp. 564-568.

Alnuaimi, A.S., Taha, R.A., Al-Mohsin, M., and Al-Harthi, A.S. (2010). Causes, effects, benefits, and remedies of change orders on public construction projects in Oman. Journal of Construction Engineering and Management 136(5), pp. 615-622.

Aneesha, K., and Haridharan, M.K. (2017). Ranking the project management success factors for construction projects in South India. Proceedings of the IOP Conference Series: Earth and Environment Science 80(1), Tirumalaisamudram, Thanjavur, India, pp. 012044 .

Ashley, D.B., Lurie, C.S., and Jaselskis, E.J. (1987). Determinants of construction project success. Project Management Journal 18(2), pp. 69-79.

Baker, B.N., Murphy, D.C., and Fisher, D. (1988). Factors affecting project success. In Cleland, D.I. and King, W.R. (Eds.), Project Management Success, $2^{\text {nd }}$ Ed., John Wiley \& Sons, New York, pp. 902-909.

Ballard, G., and Koskela, L. (1998). On the agenda for design management research. Proceedings of the 6th Annual Conference of the International Group for Lean Construction, Guaruja Beach, Brazil.

Bangi, P., Sharma, M.K., and Godla, J.K. (1999). Critical issues affecting an ERP implementation. Information System Management 16(3), pp. 7-14. 
Barney, J.B. (1991). Firm resources and sustained competitive advantage. Journal of Management 17(1), pp. 99-120.

Barney, J.B. (1986). Organisational culture: Can it be a source of sustained competitive advantage? The Academy of Management Review 11(3), pp. 656-665.

Barney, J.B., and Hansen, M.H. (1994). Trustworthiness as a source of competitive advantage. Strategic Management Journal 15(1), pp. 175-190.

Barron, M., and Barron, A.R. (2009). History of project management. The Project Management Hut, available from: https://pmhut.com/history-of-projectmanagement [accessed May 23, 2019].

Bayilev, Y.T., and Teklu, G.K. (2016). Success factors and criteria in the management of international development projects: Evidence in projects funded by the European Union in Ethiopia. International Journal of Managing Projects in Business 9(3), pp. 562-582.

Belassi, W., and Tukel, O.I. (1996). A new framework for determining critical success factors in projects. International Journal of Project Management 14(3), pp. 141-151.

Belout, A. (1998). Effects of human resource management on project effectiveness and success: Toward a new conceptual framework. International Journal of Project Management 16(1), pp. 21-26.

Bertisen, J., and Davis, G.A. (2008). Bias and error in mine project capital cost estimation. The Engineering Economist 53(2), pp. 118-139.

Bond-Barnard, T., Fletcher, L., and Steyn, H. (2018). Linking trust and collaboration in projects teams to project management success. International Journal of Managing Projects in Business 11(2), pp. 432-457.

Bondarouk, T., Trullen, J., and Vulverde, M. (2019). It's never a straight line: Advancing knowledge on HRM implementation. The International Journal of Human Resources Management 29 (Special Issue), pp. 29953000 .

Bourne, L., and Weaver, P. (2010). Mapping stakeholders. In Chinyio, E.A. and Olomolaiye, P. (Eds.), Construction Stakeholder Management, Blackwell Publishing, London, pp. 99-120.

Boutelle, J. (2004). Understanding organisational stakeholders for design success. Proceedings of the 2004 Conference on Designing Interactive Systems: Processes, Practices, Methods, and Techniques, ACM Press, New York.

Bradly, J. (2019). Organisational behaviour \& human resource theories. Chron.com, available from: https://smallbusiness.chron.com/organizationalbehavior-human-resource-theories-74260.html [accessed April 13, 2020].

Buvik, M., and Tvedt, S.D. (2017). The influence of project commitment and team commitment on the relationship between trust and knowledge sharing in project teams. Project Management Journal 48(2), pp. 5-21.

Campbell, M. (2009). Communications Skills for Project Managers. Amacom, New York.

Chan, A.P.C., and Yeong, C.M. (1995). A comparison of strategies for reducing variations. Construction Management and Economics 13(6), pp. 467-473.
Chan, D.W.M., and Kumarasamy, M.M. (1997). A comparative study of causes of time overruns in Hong Kong construction projects. International Journal of Project Management 15(1), pp. 55-63.

Chan, W.K., Zailani, S., and Fernando, Y. (2009). Critical factors influencing the project success amongst manufacturing companies in Malaysia. African Journal of Business Management 3(1), pp. 16-27.

Chen, M. (1997). Modern project manager. Cost Engineering 39(3), pp. 27-30.

Cleland, D.I. (1984). Metric Management System Handbook, Van Nortrand Reinfold, New York.

Cleland, D.I. (1999). Project Management: Strategic Design and Implementation, $3^{\text {rd }}$ Ed., McGraw-Hill, New York.

Cleland, D.I. (2004). The evolution of project management. IEEE Transactions on Engineering Management 51(4), pp. 396-397.

Cleland, D.I., and Gareis, R. (1994). Global Project Management Handbook, McGraw-Hill, New York.

Cohen, D., and Prusak, L. (2001). In Good Company: How Social Capital Makes Organisations Work, Harvard Business School Press, Harvard, MA.

Collinge, B. (2016). Stakeholder management strategies during construction project work. British Journal of Healthcare Management 22(8), pp. 394-400.

Cooke-Davies, T.J. (2002). The real success factors in projects. International Journal of Project Management 20(3), pp. 185-190.

Cooke-Davies, T.J. (2014). Sponsoring projects: Developing an organisational capability. Proceedings of the $6^{\text {th }}$ Concept Symposium on Projects Governance, Norway, available from: http://www.concept.ntnu.no/english [accessed April 18, 2020].

Creedy, G.D. (2006). Risk Factors Leading to Cost Overruns in the Delivery of Highway Construction Projects. Unpublished doctoral dissertation, Queensland University of Technology, Brisbane, Australia.

Dadashzadeh, M. (1989). An improved division operator for relational algebra. Information Systems 14(5), pp. 431437.

Davis, K. (2014). Different stakeholder groups and their perceptions of project success. International Journal of Project Management 32(2), pp. 189-201.

De Silva, N., Rajakaruna, R.W.D.W.C.A.B., and Bandara, K.A.T.N. (2008). Challenges faced by the construction industry in Sri Lanka: Perspective of clients and contractors. Proceedings of the International Conference in Building Education and Research, Sri Lanka, pp. 158-169.

De Wit, A. (1988). Measurement of project success. International Journal of Project Management 6(3), pp. 164-170.

Demilliere, A.S. (2014). The role of human resource in project management. Romanian Distribution Committee Magazine 5(1), pp. 36-40.

Deming, W.E. (1986). Out of the Crisis: Quality, Productivity and Competitive Position, $2^{\text {nd }}$ Ed., Cambridge University Press, Cambridge.

Dong, C., Chuah, K.B., and Zhai, L. (2004). A study of critical success factors of information system projects in China. Proceedings of the $3^{\text {rd }}$ PMI Research Conference, London, England. 
Dvir, D., Lipovetsky S., Shenhar A., and Tishler A. (1998). In search of project classification: A non-universal approach to project success factor. Research Policy 27(9), pp. 915-935.

Dvir, D., Sadeh, A., and Malach-Pines, A. (2006). Project and project managers: The relationship between project manager's personality, project type and project success. Project Management Journal 37(5), pp. 36-48.

El-Gohary, N.M., Osman, J., and El-Diraby, T.E. (2006). Stakeholder management for public private partnerships. Journal of International Project Management 24(7), pp. 595-604.

Engwall, M., and Jerbrant, A. (2003). The resources allocation syndrome: Prime challenge of multi-project management. International Journal of Project Management 21, pp. 403-409.

Eskerod, P., and Jepsen, A.L. (2013). Project Stakeholder Management, $1^{\text {st }}$ Ed., Gower Publishing Ltd., Aldershot.

Eyiah-Botwe, E. (2015). An evaluation of stakeholder management role in GETFund polytechnics projects delivery in Ghana. Civil and Environmental Research 7(3), pp. 66-73.

Eyiah-Botwe, E., Aigbavboa, C.O., and Thwala, W.D. (2015). Critical success factors for enhanced stakeholder management in Ghana. The Scientific Journal for Theory and Practice of Socio-Economic Development 5(10), pp. 153-170.

Fitz-Enz, J. (1984). How to Measure Human Resources Management, McGraw-Hill, New York.

Flyvbjerg, B. (2004). Megaprojects and risks: A conversation with Bent Flyvbjerg. Critical Planning 11, pp. 51-63.

Flyvbjerg, B., Holm, M.K.S., and Buhl, S.L. (2003). What causes cost overrun on transport infrastructure projects? Transport Review 24(1), pp. 3-18.

Frefer, A.A., Mahmoud, M., Haleema, H., and Almamlook, R. (2018). Overview success criteria and success factors in project management. Industrial Engineering and Management, 7(1), pp. 1-6.

Ghazali, R. (2015). Transport Ministry: KLIA2 construction never experienced cost overruns, The Star Online, available from: http:/www.thestar.com.my/News/ Nation/2015 [accessed April 18, 2020].

Gudienè, N., Banaitis, A., and Banaitienè, N. (2013). Evaluation of critical success factors for construction projects: An empirical study in Lithuania. International Journal of Strategic Property Management 17(1), pp. 21-30.

Gumay, L.A., Purwandari, B., Raharjo, T., Wahyudi, A., and Purwaningsih, M. (2020), Identifying critical success factors for information technology projects with an analytic hierarchy process. Proceedings of the $20202^{\text {nd }}$ Asia Pacific Information Technology Conference, pp. 108-112.

Gunasekera, V.S., and Chong, S.C. (2018). Knowledge management for construction organisations: A research agenda. Kybernetes 47(9), pp. 1778-1800.

Haider, N.I., Aziz, S., and Kashif-ur-Rehman (2011) The impact of stakeholder communication on project outcome. African Journal of Business Management 5(14), pp. 5824-5832.
Hamilton, A. (2007). Project design: Task that need to be managed. Proceedings of the Institution of Civil Engineers-Management, Procurement \& Law 160(1), pp. 17-23.

Han, S., Love, P., and Peña-Mora, F. (2013). A system dynamics model for assessing the impacts of design errors in construction projects. Mathematical and Computer Modelling 57(9-10), pp. 2044-2053.

Handler, J.F. (1996). Down from Bureaucracy: The Ambiguity of Privatisation and Empowerment, Princeton University Press, Princeton, New Jersey.

Haron, N.A., Jassim, S., Alias, A. H., Tahir, M.M., and Harun, A.N. (2017). Project management practices and its effects on project success in Malaysian construction industry. Proceedings of the International Conference on Architecture and Civil Engineering, Petaling Jaya, Malaysia

Harrison, E.L. (1992). Advanced Project Management: A Structured Approach, $3^{\text {rd }}$ Ed., Gower Publishing Limited, Aldershot.

Huemann, M., Keegan, A., and Turner, J.R. (2007). Human resource management in the project-oriented company: A review. International Journal of Project Management 25(3), pp. 315-323.

Hughes, W.P. (1989). Identifying environment of construction projects. Construction Management and Economics 7(1), pp. 29-40.

Jacobs, F.R., and Chase, R.B. (2018). Operations and Supply Chain Management, $15^{\text {th }}$ Ed., McGraw-Hill Education, New York.

Jacobsen, D.I., and Thorsvik, J. (2007). Hvordan Organisasjoner Fungerer, Fagbokforlaget, Bergen.

Jepsen, A.L., and Eskerod, P. (2009). Stakeholder analysis in projects: Challenges in using current guidelines in the real world. International Journal of Project Management 27(4), pp. 335-343.

Jergeas, G.F., Williamson, E., Skulmoski, G.J., and Thomas, J.L. (2000). Stakeholder management on construction projects. AACE International Transaction 12(1), pp. 16.

Jha, K.N., and Iyer, K.C. (2007). Commitment, coordination, competence and the iron triangle. International Journal of Project Management 25(5), pp. 527-540.

Johnson, J. (1999). Turning chaos into success. Software Magazine 19(3), pp. 30-34.

Kaming, P.F., Olomolaiye, P., Holt, G.D., and Harris, F.C. (1997). Factors influencing construction time and cost overruns on high-rise projects in Indonesia. Construction Management and Economics 15(1), pp. 83-94.

Keeling, R. (2000). Project Management: An International Perspective, St. Martin Press, New York.

Kerzner, H.R. (1998). In Search of Excellence in Project Management, Van Nostrand Reinhold, New York.

Kerzner, H.R. (2009). Project Management: A Systems Approach to Planning, Scheduling and Controlling, $10^{\text {th }}$ Ed., John Wiley \& Sons, New York.

Kerzner, H.R. (2006). Project Management: A Systems Approach to Planning, Scheduling and Controlling, Van Nostrand Reinhold, New York.

Kezsbom, D.S., Schilling, D.L., and Edward, K.A. (1989). Dynamic Project Management: A Practical Guide for 
Managers and Engineers, John Wiley \& Sons, New York.

Koskela, L.J. (1992). Application of the New Production Philosophy to Construction, CIFE Technical Report \#72, Stanford University.

KPMG. (2012). Project and Programme Management Survey, KPMG Advisory, N.V. Project Management Institute, Amstelveen, Netherlands.

Kumar, V., Han, Y., Trương, N.T., Hoang, N.Y.N., and Upadhyay, A. (2021). Understanding the interrelationship between culture of quality, employee, and organisational performance. Operations and Supply Chain Management: An International Journal 14(1), pp. 14-25.

Larkin, T.J., and Larkin, S. (1996). Reaching and changing frontline employees. Harvard Business Review 74(3), pp. 95-104.

Laufer, A., Denker, G.R., and Shenhar, A.J. (1990). Simultaneous management: The key to excellence in capital projects. International Journal of Project Management 14(4), pp. 189-199.

Lee, F-H., Lee, F-Z., and Wu, W-Y. (2010). The relationship between human resource management practices, business strategy and firm performance: Evidence from steel industry in Taiwan. The International Journal of Human Resource Management 21(9), pp. 1351-1372.

Leidecker, J.K., and Bruno, A.V. (1984). Identifying and using critical success factors. Long Range Planning 17(1), pp. 23-32.

Leung, M.Y., Chong, A., Ng, S.T., and Cheung, M.C.K. (2004). Demystifying stakeholders' commitment and its impacts on construction projects. Construction Management and Economics 22(7), pp. 701-715.

Li, Y., Song, H., Sang, P., and Chan, P.H. (2019). Review of critical success factors for green buildings. Building and Environment 158, pp. 182-191.

Liang, X, Yu. T., and Guo, L. (2017). Understanding stakeholders' influence on project success with a new SNA method: A case study of the green retrofit in China. Sustainability 9(10), pp. 1-19.

Limodio, N. (2011). The Success of Infrastructure Projects in Low-Income Countries and the Role of Selectivity, Policy Research Working Paper 5694, Research Support Unit, Development Economics Vice Presidency, The World Bank, available from: http://documents.worldbank.org/curated/en/85733146 8176676870/pdf/WPS5694.pdf [accessed May 23, 2019].

Lovins, A.B., Hawken, P., and Lovins, L.H. (1999). Natural Capitalism: Creating the Next Industrial Revolution, Earthscan, London.

Mali, A.P., and Waghmare, A.P. (2016). Embodied energy audit of residential building. International Journal of Advanced Engineering, Management and Science 2(7), pp. 1141-1147.

Mandson, L., and Selnes, M. (2015). Project Management Efficiency and Effectiveness to Improve Project Control in Public Sector. Unpublished Master's thesis, NTNU Trondheim Norwegian University of Science and Technology.

Mayfield. M., Mayfield, J., and Wheeler. C (2016). Talent development for top leaders: Three HR initiative for competitive advantage. Human Resource Management International Digest 24(6), pp. 4-7.

Mir, F.A., and Pinnington, A.H. (2014). Exploring the value of project management: Linking project management performance and project success. International Journal of Project Management 32(2), pp. 202-217.

Mohamed, A.A. (2001). Analysis and Management of Change Orders for Combined Sewer Over Flow Construction Projects. Unpublished dissertation, Wayne State University.

Mohandas, V.P., and Sankaranarayanan, S.R. (2008). Cost of quality analysis: Driving bottom-line performance. International Journal of Strategic Cost Management 3(2), pp. 1-8.

Mok. K.Y., Shen, G.S., and Jing, B. (2015). Stakeholder management studies in mega construction projects: A review and future directions. International Journal of Project Management 33(2), pp. 446-457.

Morris, P.W.G. (2000). Researching the unanswered questions of project management. Proceedings of PMI Research Conference, Paris, France, pp. 87-101.

Multaharju, S. (2016). Framework of stakeholder reactions on sustainability risk mitigation practices and sustainability performance in supply chains. Operations and Supply Chain Management: An International Journal 9(3), pp. 172-183.

Newton, R. (2008). The Practice and Theory of Project Management: Creating Value through Change, Palgrave Macmillan, New York.

$\mathrm{Ng}$, E. (2015). No cost overrun for KLIA2, says Liow, The Edge Markets, available from: http://www.theedgemarkets.com/my/article/no-costoverrun-klia2-says-liow [accessed May 27, 2015].

Nguyen, L.D., Oguniana, S.O., and Xuan Lan, D.T. (2004). A study on project success factors in large construction projects in Vietnam. Engineering, Construction and Architectural Management 11(6), pp. 404-413.

Nicholas, J.M. (1994). Managing Business and Engineering Projects: Concepts and Implementation, Prentice Hall, Englewood Cliffs, New Jersey.

Nicholas, J.M. (1989). Successful project management: A force-field analysis. Journal of Systems Management 40(1), pp. 24-30.

Nicolini, D. (2002). In search of project chemistry, Construction Management and Economics 20(2), pp. 167-177.

Odeck, J. (2004). Cost overruns in road construction: What are their sizes and determinants? Transport Policy 11(1), pp. 43-53.

Ogwueleka, A.C. (2013). A review of safety and quality issues in the construction industry. Journal of Construction Engineering and Project Management 3(3), pp. 42-48.

Olawale, Y.A., and Sun, M. (2010). Cost and time control of construction projects: Inhibiting factors and mitigating measures in practice. Construction Management and Economics 28(5), pp. 509-526.

Orangi, A., Palaneeswaran, E., and Wilson, J. (2011). Exploring delays in Victoria-based Australian pipeline projects. Procedia Engineering 14, pp. 874881. 
Park, S. H. (2009). Whole life performance assessment: Critical success factors. Journal of Construction Engineering 135(11), pp. 1146-1161.

Payne, J.H. (1995). Management of multiple simultaneous projects: A state-of the-art review. International Journal of Project Management 13(3), pp. 163-168.

Pinto, J.K., and Prescott, J.E (1988). Variation in critical success factors over the stages in the project cycle. Journal of Management 14(1), pp. 5-18.

Pinto J.K., and Slevin, D.P. (1987). Critical factors in successful project implementation. IEEE Transactions on Engineering Management 3(4), pp. 22-27.

Pinto J.K., and Slevin, D.P. (1988). Critical success factors across the project life cycle. Project Management Journal 19(3), pp. 67-75.

Pryke, S., and Smyth, H. (2006). The Management of Complex Projects: A Relationship Approach, WileyBlackwell, Chichester.

PWC. (2018). Project Success Survey: Driving Project Success in Belgium, available from: https:/www.pwc.be >publication > project [accessed April 13, 2020].

Rockart, J.F. (1979). Chief executives define their own data needs. Harvard Business Review 57(2), pp. 81-93.

Rogers, L. (1990). Project team training: A proven key to organisational teamwork and breakthrough in planning performance. Project Management Journal 11(2), pp. 9-17.

Sahlin, J.P. (1998). How much technical training does a project manager need? PM Network 12(5), pp. 35-36.

Sansone, C., Hilletofth, P., and Eriksson, D. (2020). Critical operations capabilities for competitive manufacturing in a high-cost environment: A multiple case study. Operations and Supply Chain Management: An International Journal 13(1), pp. 94-107.

Saqib, M., Farooqui, R.U., and Lodi, S.H. (2008). Assessment of critical success factors for construction project in Pakistan. Proceedings of the $1^{\text {st }}$ International Conference on Construction in Developing Countries: Advancing and Integrating Construction Education Research and Practice, Karachi, Pakistan.

Schuler, R.S. (1992). Strategic human resource management: Linking people with the needs of the business. Organisational Dynamics 21(1), pp. 18-32.

Shah, A., Khan, S., Shah M.H., Khan, R., and Jan, I.U. (2010). Environmental impact assessment (EIA) of infrastructure development projects in development countries. OIDA International Journal of Sustainable Development 1(4), pp. 47-54.

Silva, G.A.S.K, Warnakulasuriya, B.N.F., and Arachchige, B.J.H. (2015). Critical success factors for construction projects: A literature review. Proceedings of $12^{\text {th }}$ International Conference on Business Management, Colombo, Sri Lanka.

Somers, T.M., and Nelson, K. (2001). The impact of critical success factors across the stages of enterprise resource planning implementations. Proceedings of the $34^{\text {th }}$ Hawaii International Conference on System Sciences, IEEE Computer Society, Los Alamitos.

Spalek, S. (2005). Critical success factors in project management. To fail or not to fail, that is the question! Proceedings of the PMI Global Congress 2005,
EMEA, Edinburgh, Scotland, Project Management Institute, Newton Square, PA.

Stasinopoulos, P., Smith, M.H., and Hargrove, K.C. (2009). Whole System Design: An Integrated Approach to Sustainable Engineering, available from: http://doi.org/10,1177/097340820900300225 [accessed April 13, 2020].

Swift, C. (2019). Stakeholder management: Your 10minutes guide to winning support. Emerald Works, available from: https://emeraldworks.com/resources/blog/ freedownload/stakeholder-management-10-min-guide [accessed April 13, 2020].

Taherdoost, H., and Keshavarzsaleh, A. (2015). Critical factors that lead to project success/failure in global marketplace. Proceedings of the $9^{\text {th }}$ International Conference Interdisciplinary in Engineering, TirguMures, Romania, pp. 1066-1075.

Thomsett, R. (2002). Radical Project Management, Prentice Hall, Upper Saddle River, New Jersey.

Thornberry, N.E. (1987). Training the engineer as project manager: How to turn technical types into top-notch project managers. Training and Development Journal 4(1), pp. 67-69.

Toor, S.U.R., and Ogunlana, S.O. (2008). Problems causing delays in major construction projects in Thailand. Construction Management and Economics 26(4), pp. 395-408.

Ugwu O.O., Kumaraswamy, M.M., Ng, T., and Lee, P.K.K. (2006). Information \& Communication Technology (ICT) Applications in Construction, Report of Surveys on ICT Applications, Benchmarks, Benefits, Costs, Barriers \& Enablers, and Research \& Development Issues in the HKSAR Construction Industry, Centre for Innovation in Construction and Infrastructure Development, The University of Hong Kong, Hong Kong, ISBN 962-86246-4-4

Ulrich, D. (1987). Organisation capability as a competitive advantage: Human resource professionals as strategic partners. Resource Planning 10(4), pp. 169-184.

Vasista, T.G.K. (2017). Strategic cost management for construction project success: A systematic study. Civil Engineering and Urban Planning: An International Journal 4(1), pp. 41-52.

Verma, V.K. (1996). Human Resource Skills for the Project Manager, Project Management Institute, Newton Square, Pennsylvania.

Verma, V.K. (1995). Organising Project for Success, Project Management Institute, Newton Square, Pennsylvania.

Viles, E., Rudeli, N.C., and Santilli, A. (2019). Causes of delay in construction projects: A quantitative analysis. Engineering, Construction and Architectural Management 27(4), pp. 917-935.

Walker, A. (1989). Project Management in Construction, $2^{\text {nd }}$ Ed., BSP Professional Books, Oxford.

Washington State Department of Transportation. (2015). Cost Estimating Manual for Project, available from: www.wsdot.wa.gov/publications/manual [accessed April 13, 2020].

Yap, J.B.H., Abdul-Rahman, H., and Wang, C. (2015). Impacts of design changes on construction project performance: Insights from a literature review. 
Proceedings of the 14th Management in Construction Research Association (MiCRA 2015) Conference and Annual General Meeting, Kuala Lumpur, Malaysia.

Yudhistyra, W.I., Risal, E.M., Raungratanaamporn, I-S., and Ratanavaraha, V. (2020). Exploring big data research: A review of published articles from 2010 to 2018 related to logistics and supply chains. Operations and Supply Chain Management: An International Journal 13(2), pp. 134-149.
Zhang, Z.X. (2011). Policies and Measures to Mitigate Potential Environmental Impacts of Cross Border infrastructure Projects in Asia, ADB Working Paper 261, Asian Development Bank Institute.

\section{Further readings}

International Training Centre. (2010). Project Design Manual, available from: https:// www.ilo.org

PMBOK Guide. (2017). A Guide to the Project Management Body of Knowledge (PMBOK ${ }^{\circledR}$ Guide), $6^{\text {th }}$ Ed., Project Management Institute, Newton Square, PA.

Sarath Herath is currently the Chairman of Sintech Engineering and Chief Executive Officer of Sierra Technology Holdings in Sri Lanka. He is a Chartered Engineer and a Fellow of both Institutions of Mechanical and Marine Engineers in the UK. He worked in the oil and gas industry in design and project management for both producing and consulting companies in several countries. Sarath Herath is currently completing his doctoral degree at Management and Science University (MSU) in Malaysia.

Dr Siong-Choy Chong is currently the Chief Technical Officer (Quality Assurance) at Finance Accreditation Agency, Malaysia. He was formerly a Professor and Deputy Vice-Chancellor for Academic and Research in one of the institutions of higher learning in Malaysia. Dr Chong has published more than 150 papers in international journals, conference articles and book chapters, as well as supervised 11 doctoral candidates to completion. 